\title{
A Portable Setup for the Voltammetric Determination of Total Mercury in Fish with Solid and Nanostructured Gold Electrodes
}

\author{
Andrea Ruo Redda ${ }^{1}$, Ornella Abollino ${ }^{2}\left(\mathbb{D}\right.$, Mery Malandrino ${ }^{2}\left(D\right.$, Stefania Squadrone ${ }^{3}$, \\ Maria Cesarina Abete ${ }^{3}$, Silvia Berto ${ }^{2}$, Rosanna Toniolo ${ }^{4}$, Francesca Durbiano ${ }^{5}$ \\ and Agnese Giacomino $1, * \mathbb{C}$ \\ 1 Department of Drug Science and Technology, University of Torino, 10125 Torino, Italy; \\ ruoreddaandrea@tiscali.it \\ 2 Department of Chemistry, University of Torino, 10125 Torino, Italy; ornella.abollino@unito.it (O.A.); \\ mery.malandrino@unito.it (M.M.); silvia.berto@unito.it (S.B.) \\ 3 Istituto Zooprofilattico Sperimentale del Piemonte, Liguria e Valle d'Aosta (IZSPLV), 10100 Torino, Italy; \\ stefania.squadrone@izsto.it (S.S.); mariacesarina.abete@izsto.it (M.C.A.) \\ 4 Department of Agricultural, Food, Animal and Environmental Sciences, University of Udine, \\ 33100 Udine, Italy; rosanna.toniolo@uniud.it \\ 5 National Institute of Metrological Research, Physical Chemistry and Nanotechnology Division, \\ 10135 Torino, Italy; f.durbiano@inrim.it \\ * Correspondence: agnese.giacomino@unito.it; Tel.: +39-011-6705679
}

Academic Editors: Giuseppe Scarponi, Silvia Illuminati, Anna Annibaldi and Cristina Truzzi Received: 29 March 2019; Accepted: 16 May 2019; Published: 17 May 2019

\begin{abstract}
A simple procedure for field fish sample pretreatment was developed. This treatment in combination with square wave anodic stripping voltammetry (SW-ASV) with solid gold electrodes (SGE) and gold nanoparticle-modified glassy carbon electrodes (AuNPs-GCE) was applied for the determination of total mercury content. A certified reference material (CRM, Tuna Fish BCR 463), ten freeze-dried samples of canned tuna and two fresh fish samples were analysed both with a bench-top voltammetric analyser after microwave digestion and with a portable potentiostat after mild eating using a small commercial food warmer. The results obtained by the two SW-ASV approaches and by a Direct Mercury Analyser (DMA), the official method for mercury determination, were in very good agreement. In particular, (i) the results obtained with in field procedure are consistent with those obtained with the conventional microwave digestion; (ii) the presence of gold nanoparticles on the active electrode surface permits an improvement of the analytical performance in comparison to the SGE: the Limit of Quantification (LOQ) for mercury in fish-matrix was $0.1 \mu \mathrm{g} \mathrm{L}^{-1}$ (Hg cell concentration), corresponding to $0.06 \mathrm{mg} \mathrm{kg}^{-1}$ wet fish, which is a performance comparable to that of DMA. The pretreatment proposed in this study is very easy and applicable to fresh fish; in combination with a portable potentiostat, it proved to be an interesting procedure for on-site mercury determination.
\end{abstract}

Keywords: mercury; gold electrodes; direct mercury analyser; on-site analysis; anodic stripping voltammetry

\section{Introduction}

Mercury emissions have increased above natural environmental levels due to anthropogenic practices, such as coal combustion, mining activities and industrial processes, whereas natural releases are mainly due to volcanoes [1]. 
Due to its long residence time in atmosphere, $\mathrm{Hg}$ has the possibility to travel throughout the world, impacting remote regions, such as the open ocean [2]. When elemental mercury is introduced into aquatic ecosystems, it is oxidised to inorganic compounds and then methylating microbes participate to form organic species, such as methylmercury (MeHg) [3,4]. In this chemical form, mercury shows a low hydrophilicity and can interact with cell membranes and proteins: the affinity with the components of living organisms leads to a bio-accumulation of these $\mathrm{Hg}$ species in the life forms placed at the top of the food chain [3]. For this reason, fish represents a critical source of $\mathrm{Hg}$ and $\mathrm{MeHg}$ into human diet [5].

For the determination of this element in fish, fishery products and other biological tissues, cold-vapour atomic absorption spectrometry (CVAAS) or cold-vapour atomic fluorescence spectrometry (CVAFS) can be used. CVAAS is used to determine total $\mathrm{Hg}$ in a sample at concentrations levels of at least $200 \mu \mathrm{g} \mathrm{kg}^{-1}$ [6-8]; CVAFS presents a low detection limit and it allows for performing measurements with a smaller amount of sample in comparison to CVAAS, but it is not widely used because it is rather expensive. In the last several years, a new device for a direct mercury analysis has been developed, which automatically performs both sample digestion and $\mathrm{Hg}$ detection by AAS, with short analysis times and a low limit of quantitation (LOQ), namely $0.010 \mathrm{mg} \mathrm{kg}^{-1}$ wet weight [9].

Several electrochemical methods have been developed for mercury determination in different matrices, especially in aqueous samples [10]. Focusing the attention on fish-based matrices, most of the electrochemical methods rely on anodic stripping voltammetry (ASV), involving a first step of preconcentration of $\mathrm{Hg}$ by reduction onto the working electrode (WE) and a second one of oxidative stripping.

In particular, the U.S. Environmental Protection Agency (US EPA) issued a method for mercury determination by ASV using a glassy carbon electrode (GCE) modified with a gold film: this modification is very simple and permits for obtaining a low limit of detection (LOD $=0.1 \mu \mathrm{g} \mathrm{L}{ }^{-1}$ ) and to work with a renewable surface [10-12]. Screen-printed carbon electrodes (SPCEs) modified with gold film have been employed, achieving LODs of $0.9 \mu \mathrm{g} \mathrm{L}^{-1}$ [13]. Tamer et al. used a platinum electrode modified with poly(3-hexylthiophene) obtaining an LOD of $5 \mu \mathrm{g} \mathrm{L}{ }^{-1}$ [14]. In addition, carbon paste electrodes (CPEs) modified with several species able to complex and preconcentrate $\mathrm{Hg}$ (II) have been used. In these cases, LODs were in the range $0.18-0.5 \mu \mathrm{g} \mathrm{L}^{-1}$ [15-17]. Many studies have used gold nanoparticle (AuNPs)-modified electrodes for voltammetric sensing $[18,19]$. Gold is an appropriate substrate for the electrochemical determination of $\mathrm{Hg}$ because of its high affinity toward this element that can increase preconcentration effect [20]. Moreover, AuNPs show unique properties such as high conductivity, good biocompatibility, and large specific surface area and can bind to the surface of many polymers through covalent bonding to functional groups such as $\mathrm{CN}, \mathrm{NH}_{2}$, and $\mathrm{SH}$ [21]: these properties are very attractive for sensors and biosensors.

The recent scientific literature continues to focus the attention on the development of new sensors for the determination of mercury in different matrices, water in particular (Table 1). Interesting chemical modifications have been proposed, but they are often not applicable for routine analysis, for mercury quantification in complex matrices.

An advantage of electrochemical analysis is that inexpensive, simple and fast measurements can be performed with miniaturized and portable instrumentation. However, most real samples have to be pretreated to dissolve the matrix and/or to extract mercury. For this purpose, in most cases, the samples have to be processed with concentrated acid extractant solutions and/or digested using a microwave oven in laboratory. Therefore, the portability of the electrochemical methods cannot be widely exploited and it is often limited to the analysis of natural waters.

For these reasons, in this study, a simple procedure for the on-site sample pretreatment (Portable Treatment, $\mathrm{P}_{\mathrm{T}}$ ) of fish samples was developed and the results obtained were compared to those obtained following the microwave treatment $\left(\mathrm{M}_{\mathrm{T}}\right)$. Mercury content in a Certified Reference Material (CRM), namely Tuna Fish of Community Bureau of Reference, European Commission (BCR) 463, in ten commercial canned tunas (CTs) after freeze-drying, in a fresh tuna fish (TF) and in a fresh swordfish (SF) was determined by ASV coupled to a solid gold electrode SGE and to a home-made AuNPs-GCE. 
Table 1. Sample matrix, pretreatment, detection limit and linear dynamic range obtained using anodic stripping voltammetry (ASV) with different electrodes for the determination of mercury, reported in papers published in 2019.

\begin{tabular}{|c|c|c|c|c|c|c|}
\hline Matrix & Pretreatment & Electrode & Method & Linear Range ( $\left.\mu \mathrm{g} \mathrm{L}^{-1}\right)$ & $\operatorname{LOD}\left(\mu \mathrm{g} \mathrm{L}^{-1}\right)$ & Ref \\
\hline Tap water & - & $\mathrm{FeOOH} / \mathrm{NPG}^{\mathrm{a}}$ microelectrode & SWV & $4.01-441$ & 1.57 & [22] \\
\hline Fish oil & $\begin{array}{l}\text { Sample was added } \\
\text { with } \mathrm{HCl} \text { and } \mathrm{H}_{2} \mathrm{O}_{2} \\
\text { sonicated-diluted }\end{array}$ & $\begin{array}{l}\text { Sputtered Ag-Au-Au } \\
\text { electrodes }\end{array}$ & DPV & $0-140$ & $0.60-140$ & [23] \\
\hline $\begin{array}{c}\text { Tap water } \\
\text { and waste water }\end{array}$ & - & DNA-RGO ${ }^{b} @ A u N R-T H-S A^{c}$ & DPV & $0.2-40$ & 0.04 & [24] \\
\hline- & - & $\begin{array}{c}\text { Shrink }{ }^{\mathrm{d}} \text {-Induced } \\
\text { Microelectrode Arrays }{ }^{\mathrm{d}}\end{array}$ & SWV & $0.2-1$ & 0.09 . & [25] \\
\hline- & - & $\begin{array}{l}{\left[\operatorname{Ir}(\mathrm{TPQ})_{2}\left(4-\mathrm{EO}_{2}-\text { pic }\right)\right]^{\mathrm{e}} \text { paper }} \\
\text { based chemosensor }\end{array}$ & & - & $3 \times 10^{-3}$ & [26] \\
\hline Water sample & - & $\mathrm{PXO}^{\mathrm{f}}$-film modified electrode & DPV & $0.13-20.5$ & 0.04 & [27] \\
\hline Sea water & - & DNA/PMET-AuNPs/PGE $\mathrm{g}$ & SWV & $0.01 \times 10^{-11}-0.02$ & $8 \times 10^{-13}$ & [28] \\
\hline River water & - & $\begin{array}{l}\text { FTO }^{\text {h }} \text { coated with } \\
\text { PA6/CNW:rGO }\end{array}$ & DPV & 501-15044 & 1.4 & [29] \\
\hline $\begin{array}{l}\text { Waste water, tap } \\
\text { water drinking water }\end{array}$ & - & $\mathrm{RS}^{\mathrm{j}}$-gRGO ${ }^{\mathrm{k}}$-GCE & DPV & $1-40$ & 0.06 & [30] \\
\hline $\begin{array}{l}\text { Tap water, fish oil } \\
\text { tablet, human serum, } \\
\text { and urine samples } \\
\text { (spiked method) }\end{array}$ & - & Bi NPs@Gr-CNTs ${ }^{i}$ & DPV & $0.2-43500$ & 0.04 & [31] \\
\hline $\begin{array}{l}\text { Vegetables (cabbage } \\
\text { and capsicum) } \\
\text { and food } \\
\text { products (noodles) }\end{array}$ & $\begin{array}{l}\text { Samples was ashed in } \\
\text { a muffle furnace -the } \\
\text { ashes were dissolved } \\
\text { in } \mathrm{HClO}_{4} \text { and } \\
\mathrm{HNO}_{3} \text {-diluted }\end{array}$ & SPE-p-g- $\mathrm{C}_{3} \mathrm{~N}_{4} / \mathrm{O}-\mathrm{MWCNTs}{ }^{1}$ & DPV & $4.8-93$ & 0.04 & [32] \\
\hline $\begin{array}{l}\text { Lake water and tap } \\
\text { water and rice }\end{array}$ & $\begin{array}{l}\text { Water samples were } \\
\text { filtered-added with } \\
\mathrm{HNO}_{3} \text { - heated to } \\
\text { remove nitric acid. } \\
\text { Rice samples were } \\
\text { digested in a } \\
\text { microwave oven with } \\
\mathrm{HNO}_{3} \text {-diluted. }\end{array}$ & $\mathrm{Fe}_{3} \mathrm{O}_{4} / \mathrm{F}-\mathrm{MWCNTs}-\mathrm{GCE}^{\mathrm{m}}$ & SWV & $2.60-6500$ & 0.78 & [33] \\
\hline \multicolumn{7}{|c|}{$\begin{array}{l}\text { a nanoporous gold microelectrode; }{ }^{b} \text { reduced graphene oxide; }{ }^{c} \text { gold nanorods and thymine-Hg(II)-thymine } \\
\text { and streptavidin; }{ }^{d} \text { sensor based on the heat-shrinkable polymer; }{ }^{e} \text { inkjet-printed phosphorescent Iridium(III) } \\
\text { complex; }{ }^{\mathrm{f}} \text { poly xylenol orange; }{ }^{g} \text { DNA/poly-L-methionine-gold nanoparticles/pencil graphite electrode; }{ }^{\mathrm{h}} \text { fluorine } \\
\text { tin-oxide electrode; }{ }^{\mathrm{i}} \text { polyamide } 6 / \text { cellulose nanowhiskers/reduced graphene oxide; }{ }^{j} \text { rhodamine hydrazide strip; }{ }^{k} \\
\text { green reduced graphene oxide; }{ }^{i} \text { bismuth nanoparticles decorated graphene-carbon nanotubes nanocomposite; }{ }^{l} \\
\text { screen-printed electrode-porous graphitic carbon nitride nanosheets; }{ }^{\mathrm{m}} \text { magnetite nanoparticles and fluorinated } \\
\text { multiwalled carbon nanotubes. }\end{array}$} \\
\hline
\end{tabular}

The same samples were (i) treated with $\mathrm{M}_{\mathrm{T}}$ and analysed using a bench-top voltammetric analyser, (ii) treated with $\mathrm{P}_{\mathrm{T}}$ and analysed with a portable potentiostat.

SGE was chosen for its simplicity, ease of use and transport. A procedure for the quantification of mercury with the AuNPs-GCE had previously been developed by our research group: the electrode modification is easy and good results were obtained for the quantification of $\mathrm{Hg}$, in the $\mathrm{ng}^{-1}$ range, both in aqueous solutions and in (solid) certified reference materials (CRMs) [34,35]. The applicability of the AuNPs-GCE was also assessed for routine mercury determination in some freeze-dried fish samples, after acid digestion in a microwave oven [36]. The main advantages of this electrode are the possibility to work with a renewable surface and the presence of NPs, which enable fast electron transfer kinetics, increase the electroactive surface area, and reduce over-potential.

The samples were also analysed by a Direct Mercury Analyser (DMA). The results were compared with those obtained by electrochemistry in order to assess the performance of the two electrodes and the applicability of the whole field approach.

\section{Results and Discussion}

\subsection{Monitoring of the Electrode Surface}

As described in our previous papers [34,35], the deposition of AuNPs onto electrode is well visible to the naked eye through a color change of the glassy carbon surface from black to red-orange. 
Figure 1 shows a homogeneous gold coating composed of particles having an average diameter of approximately $100 \pm 25 \mathrm{~nm}$.

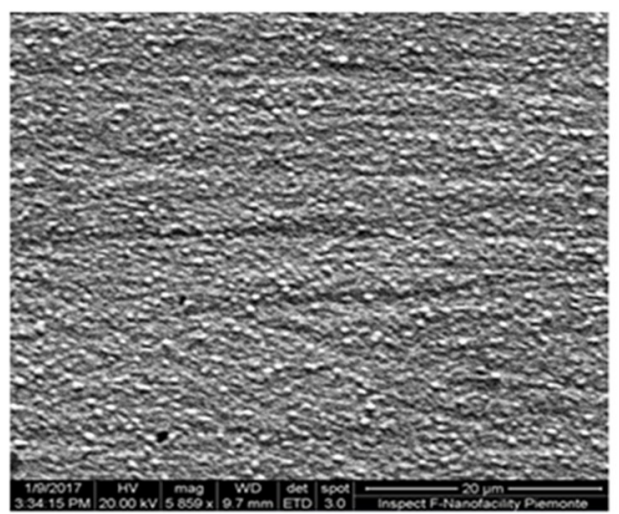

Figure 1. Scanning electrode microscopy (SEM) image of gold nanoparticles modified glassy carbon electrode (AuNPs-GCE) surface (This work has been performed at NanoFacilities Piemonte, INRiM, a laboratory supported by Compagnia di San Paolo).

A good uniformity in the distribution of the AuNPs was obtained with different GCEs and different brands of Au salts.

Cyclic voltammetry (CV) was applied to daily monitor the quality of the SGE and AuNPs-GCE surface. Figure 2 shows the voltammograms recorded in $0.5 \mathrm{M} \mathrm{H}_{2} \mathrm{SO}_{4}$ solution with the two electrodes. The obtained CV profiles are well known in literature and identify the gold surface [37-39].

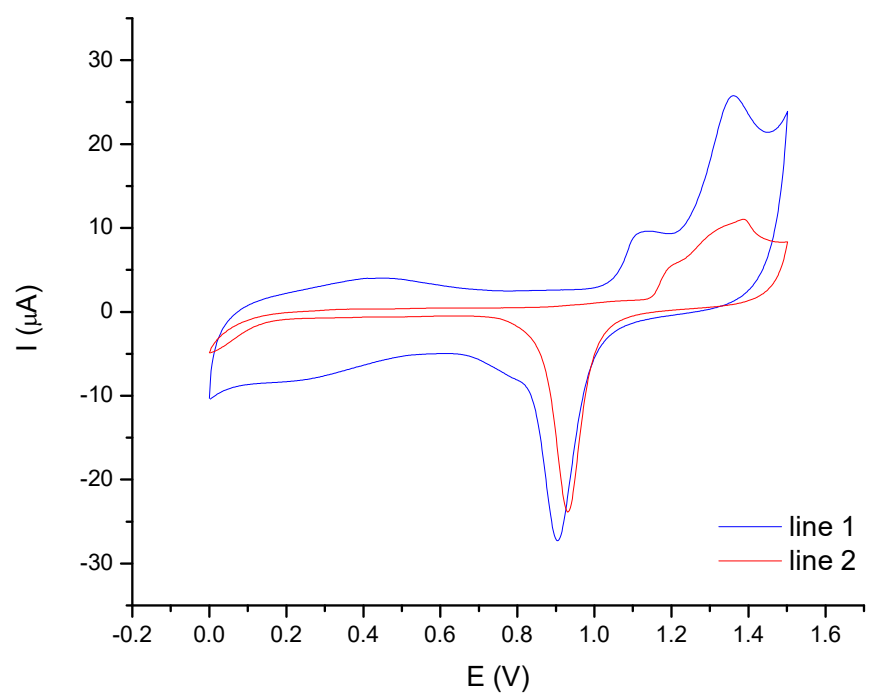

Figure 2. Cyclic voltammetry (CV)-voltammograms recorded in $0.5 \mathrm{M} \mathrm{H}_{2} \mathrm{SO}_{4}$ for gold nanoparticles modified glassy carbon electrode (AuNPs-GCE), line 1, and solid gold electrode (SGE), line 2.

If the voltammogram shows additional peaks in comparison to Figure 2, a worsening of the electrode performance is observed. These peaks are caused by the formation of multilayers of oxides in which gold can exist in different oxidation states (Au0/AuI/AuIII). After the treatments with ethanol and water, a cyclic voltammogram like that reported in figure is again obtained. When no peaks appear, the electrode is not working any more. This is due to the formation of many layers of oxides on the electrode surface that form a passivating layer on the electrode surface After the mechanical polishing with alumina powder and chemical treatment with ethanol and water, the cyclic voltammogram obtained is again like that reported in the figure. 
Ten CV-scans in $\mathrm{H}_{2} \mathrm{SO}_{4}$ were recorded before the analysis start. $\mathrm{CV}$-treatment in $\mathrm{H}_{2} \mathrm{SO}_{4}$ is also used by many researchers as activation step for noble metals-based electrodes [40]: in our experience, it is convenient to combine this procedure with a further activation step by applying a potential of $0.60 \mathrm{~V}$ for $60 \mathrm{~s}$ in $0.06 \mathrm{M} \mathrm{HCl}$ solution before mercury determination: this step is useful for removing all naturally occurring Au oxides from the surface of the electrode. The combination of these two electrochemical pretreatments permits improving the quality and the reproducibility of $\mathrm{Hg}$ signal.

\subsection{AFM Analysis}

The surface roughness of AuNPs was estimated using atomic force microscopy (AFM). Since it was not possible to directly examine the AuNPs-GCE because it does not fit to the AFM-holder, the same procedure of surface cleaning and AuNP modification for GCE was applied to a glassy carbon plate having a thickness of $3 \mathrm{~mm}$. Since it is not possible to rotate the plate during the deposition as in the case of GCE, the gold solution was maintained in agitation with a magnetic stirrer. Moreover, the glassy carbon surfaces involved in the modification are quite different: GCE has a geometric surface estimated as $\approx 3.14 \mathrm{~mm}^{2}$ on the basis of the radius provided by the producer, while the plate has an area of $2.5 \mathrm{~cm}^{2}$, estimated by direct measurement. Despite differences, AFM analysis on the GC plate confirmed the presence of a homogeneous gold layer, in agreement with scanning electron microscopy (SEM) images obtained on the AuNPs-GCE. Figure 3a shows an AFM image of the plate with the AuNPs layer on the surface. Figure 3b also reports a profile of roughness referred to the "line" drawn on the image in Figure 3a: it is possible to observe the regularity of the AuNP distribution.

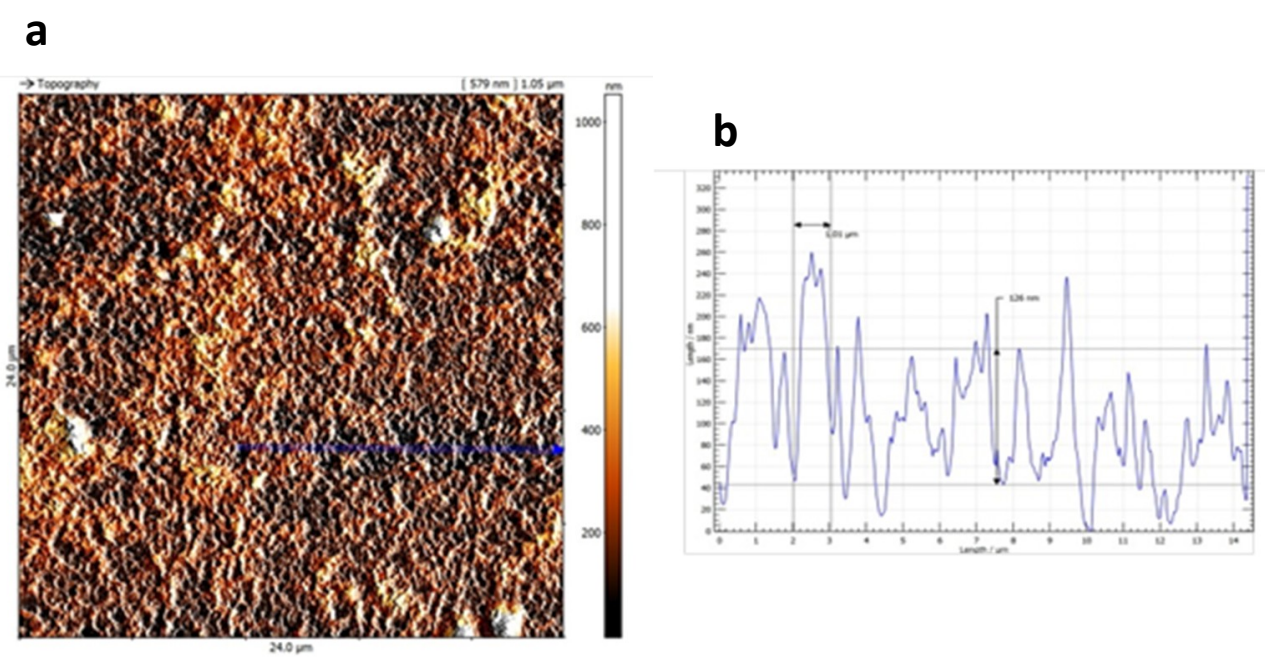

Figure 3. Atomic force microscopy (AFM) topographical image (a) and surface roughness profile (b) of an AuNP layer electrochemically deposited on a glassy carbon plate correspondent to the blue line present in Figure 3a.

\subsection{Analytical Performance of ASV Using SGE or AuNPs-GCE for Hg Determination}

Previous works [34,36] report the analytical figures of merit of the procedure (repeatability, linearity, sensitivity, trueness, and detection limit) for the determination of $\mathrm{Hg}$ in aqueous solutions considering the two electrodes) and the investigation about possible interferences in solution. Briefly, the height of $\mathrm{Hg}$ peak increases by increasing deposition time: a value of $120 \mathrm{~s}$ was found to be the best choice for the deposition of $\mathrm{Hg}$ onto SGE and AuNPs-GCE, if the concentration of Hg is less than $50 \mu \mathrm{g} \mathrm{L}{ }^{-1}$. Regarding SGE in a blank matrix $\left(0.06 \mathrm{~mol} \mathrm{~L}{ }^{-1} \mathrm{HCl}\right)$, LOD of $\mathrm{Hg}$ estimated as $3 \sigma_{\mathrm{B}} / \mathrm{slope}$ was $0.02 \mu \mathrm{g} \mathrm{L}^{-1}$, linear range $0.2-100 \mu \mathrm{g} \mathrm{L} \mathrm{L}^{-1}$ and sensitivity, calculated as the slope of the calibration curve in this range, was $1.71 \mu \mathrm{A} /\left(\mu \mathrm{g} \mathrm{L}^{-1}\right)$. The relative error for the determination of $1 \mu \mathrm{g} \mathrm{L}^{-1}$ of $\mathrm{Hg}$ was $-1 \%$. The LOD, linear range and sensitivity (in $0.06 \mathrm{molL}^{-1} \mathrm{HCl}$ ) for AuNPs-GCE were $1 \mathrm{ng} \mathrm{L}^{-1}$, $0.010-100 \mu \mathrm{g} \mathrm{L}^{-1}$ and $3.5 \mu \mathrm{A} /\left(\mu \mathrm{g} \mathrm{L}^{-1}\right)$, respectively. A concentration as low as $10 \mathrm{ng} \mathrm{L}^{-1}$ of $\mathrm{Hg}_{\text {was }}$ 
quantified with a relative error of $-0.8 \%$. Considering the low analyte concentrations expected in sample solutions, the medium exchange technique was adopted to eliminate the effect of components in the sample matrix that might cause interferences in the stripping step [41]. Using this method, an improvement of $\mathrm{Hg}$ recovery in the CRM was observed for both electrodes.

\subsection{Chronoamperometry}

Figure $4 \mathrm{a}, \mathrm{b}$ report the chronoamoperograms registered during the deposition step $(0 \mathrm{~V}, 120 \mathrm{~s})$ for $5 \mu \mathrm{g} \mathrm{L}{ }^{-1} \mathrm{Hg}$ at SGE and at AuNPs-GCE, respectively. The figures show that, in the case of AuNPs-GCE, the current values are lower than in the case of SGE but that the difference between the initial and the final registered current was higher due to the greater amount of the analyte deposited on the AuNPs-GCE proportional to the amount of gold surface present on this electrode.
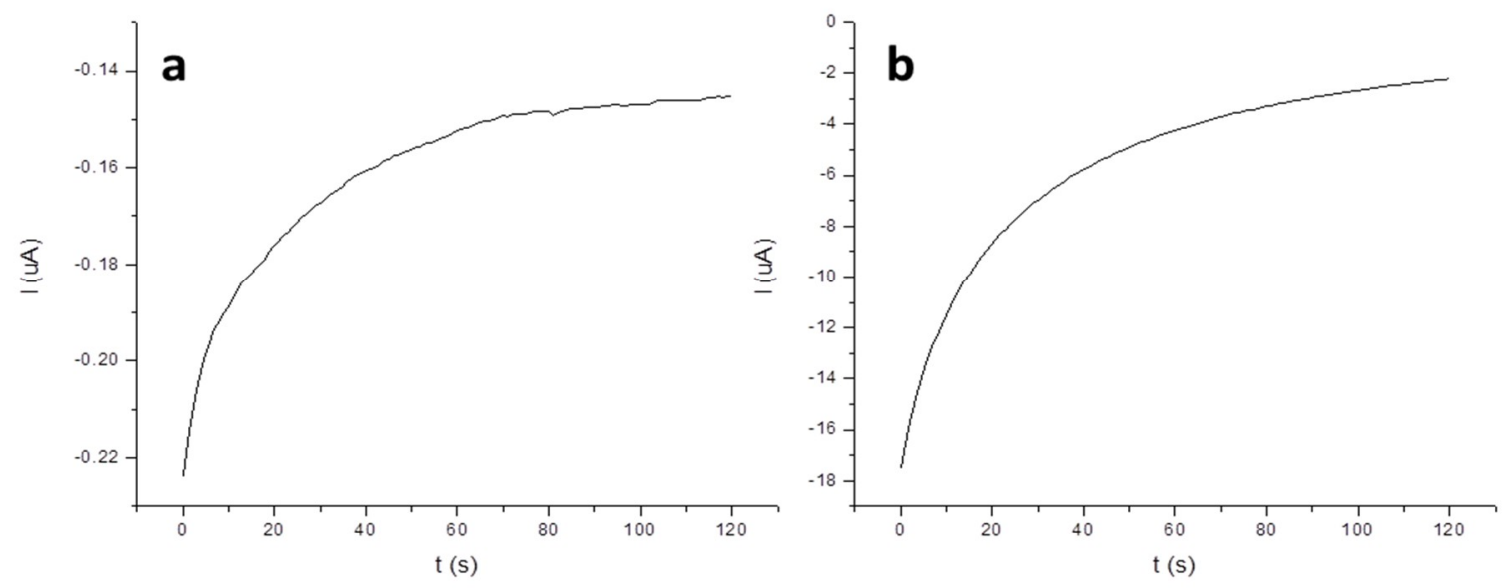

Figure 4. Chronoamperograms obtained for the deposition step of $5 \mu \mathrm{g} \mathrm{L}{ }^{-1} \mathrm{Hg}$ at $0 \mathrm{~V}$ for $120 \mathrm{~s}$ with (a) SGE and (b) AuNPs-GCE.

\subsection{Hg Determination in Fish Samples}

The concentrations found in the CRM (Certified value of $\mathrm{Hg}=2.85 \mathrm{mg} \mathrm{kg}^{-1} \pm 0.16 \mathrm{mg} \mathrm{kg}^{-1}$ ) and in the other investigated samples are reported in Table 2. In this work, the CRM and the samples were analysed also by DMA. The calibration curve obtained with DMA, $y=-3.06 \times 10^{-7} \mathrm{x}^{2}+1.10 \times$ $10^{-3} \mathrm{x}-5.5 \cdot \times 10^{-3}$, shows a good linearity, $\mathrm{R}^{2}=0.9998$. The results obtained by the DMA analysis were considered as a reference, taking into account its reliability, demonstrated by literature data [9] and by the excellent recovery obtained for the CRM.

The concentration of $\mathrm{Hg}$ found in the samples using ASV with SGE, and with AuNPs-GCE, were expressed as percentages of recovery with respect to the results obtained by DMA.

Regarding the sample solutions resulting from $\mathrm{M}_{\mathrm{T}}$, for the CRM, recoveries of $96.8 \%$ and of 99.8\% were obtained using SGE and AuNPs-GCE, respectively. In the case of the other samples, no significant mercury peaks were observed for three samples (CT3, CT4 and CT8) with the SGE, while Hg was detected in all the sample solutions with AuNPs-GCE (with recoveries between 79\% and 107\%). These results confirm that the larger surface area of the deposited AuNPs permits an enhancement of the sensitivity of the measurement in comparison with the one obtained in the case of a solid electrode surface.

Regarding the analysis of the extracts obtained by $\mathrm{P}_{\mathrm{T}}$, three different extraction solutions were tested on the CRM to value the best conditions to obtain a quantitative extraction in the field procedure. The obtained concentrations and the correspondent recoveries (\%) were $2.66 \mathrm{mg} \mathrm{kg}^{-1}$ $\pm 0.22 \mathrm{mg} \mathrm{kg}^{-1}(93.4 \%), 2.58 \mathrm{mg} \mathrm{kg}^{-1} \pm 0.43 \mathrm{mg} \mathrm{kg}^{-1}(90.5 \%)$ and $2.04 \mathrm{mg} \mathrm{kg}^{-1} \pm 0.37 \mathrm{mg} \mathrm{kg}^{-1}$ $(71.5 \%)$ using mixture $1: \mathrm{HNO}_{3} / \mathrm{H}_{2} \mathrm{O}_{2}=1: 1$; mixture 2: $\mathrm{H}_{2} \mathrm{SO}_{4} / \mathrm{HNO}_{3} / \mathrm{HClO}_{4}=5: 1: 1$ and mixture 3: $\mathrm{HNO}_{3} / \mathrm{HCl} / \mathrm{H}_{2} \mathrm{O}_{2}=5: 1: 1$, respectively. 
Table 2. Mercury concentrations ( $\mathrm{mg} \mathrm{kg}^{-1}$ of fresh weight) and recoveries (\%) obtained by DMA and ASV using SGE (with $\mathrm{MW}_{\mathrm{T}}$ ) and AuNPs-GCE (with $\mathrm{MW}_{\mathrm{T}}$ and $\mathrm{P}_{\mathrm{T}}$ ). Supporting electrolyte: $0.06 \mathrm{M}$ $\mathrm{NaCl}$ solution.

\begin{tabular}{ccccc}
\hline Sample & DMA & ASV SGE MW $_{\mathbf{T}}$ & ASV AuNPs-GCE MW $_{\text {T }}$ & ASV AuNPs-GCE P $_{\mathbf{T}}$ \\
\hline CRM $(2.85 \pm 0.16)$ & $2.86 \pm 0.06(100 \%)$ & $2.69 \pm 0.04(94.4 \%)$ & $2.77 \pm 0.09(96.8 \%)$ & $2.66 \pm 022(93.4 \%)$ \\
CT1 & $0.66 \pm 0.02$ & $0.56 \pm 0.04(84.0 \%)$ & $0.56 \pm 0.08(84.1 \%)$ & $0.58 \pm 0.01(87.1 \%)$ \\
CT2 & $0.73 \pm 0.02$ & $0.65 \pm 0.001(88.4 \%)$ & $0.63 \pm 0.07(86.3 \%)$ & $0.68 \pm 0.02(93.4 \%)$ \\
CT3 & $0.10 \pm 0.002$ & $<0.3^{*}$ & $0.10 \pm 0.01(97.3 \%)$ & $0.09 \pm 0.01(90.0 \%)$ \\
CT4 & $0.18 \pm 0.01$ & $<0.3 *$ & $0.19 \pm 0.09(106 \%)$ & $0.20 \pm 0.03(110 \%)$ \\
CT5 & $1.11 \pm 0.01$ & $1.18 \pm 0.02(106 \%)$ & $0.91 \pm 0.04(82.0 \%)$ & $0.89 \pm 0.06(80.1 \%)$ \\
CT6 & $0.91 \pm 0.03$ & $0.81 \pm 0.01(88.8 \%)$ & $0.75 \pm 0.08(81.9 \%)$ & $0.84 \pm 0.01(91.2 \%)$ \\
CT7 & $0.40 \pm 0.03$ & $0.37 \pm 0.02(91.3 \%)$ & $0.41 \pm 0.09(102 \%)$ & $0.36 \pm 0.01(89.7 \%)$ \\
CT8 & $0.28 \pm 0.01$ & $<0.3 *$ & $0.28 \pm 0.03(102 \%)$ & $0.26 \pm 0.01(92.1 \%)$ \\
CT9 & $1.43 \pm 0.07$ & $1.27 \pm 0.06(88.6 \%)$ & $1.13 \pm 0.03(79.0 \%)$ & $1.35 \pm 0.02(94.4 \%)$ \\
CT10 & $1.37 \pm 0.04$ & $1.21 \pm 0.08(88.3 \%)$ & $1.31 \pm 0.04(95.5 \%)$ & $1.21 \pm 0.04(88.3 \%)$ \\
SF & $0.55 \pm 0.05$ & $0.53 \pm 0.03(97.4 \%)$ & $0.54 \pm 0.01(98.7 \%)$ & $0.54 \pm 0.02(98.2 \%)$ \\
TF & $0.67 \pm 0.03$ & $0.63 \pm 0.08(93.8 \%)$ & $0.65 \pm 0.06(96.4 \%)$ & $0.65 \pm 0.09(96.7 \%)$ \\
\hline
\end{tabular}

DMA: direct mercury analyser; ASV: anodic stripping voltammetry; SGE: solid gold electrode; MWT = microwave treatment; AuNPs-GCE: gold nanoparticles modified glassy carbon electrode; PT = portable procedure; CT: canned tuna; TF: fresh tuna; SF: fresh swordfish ${ }^{*} \mathrm{LOQ}_{\mathrm{SGEfresh} \text { sample }}=0.3 \mathrm{mg} \mathrm{kg}^{-1}$.

Mixture 1 gave the best results in terms of recovery, probably because the high amount of hydrogen peroxide combined with nitric acid is very effective for the degradation of organic matter, even using a mild heating $\left(60-70{ }^{\circ} \mathrm{C}\right)$. The dissolution reaction proved to be slightly exothermic and the final solution was easily filterable even with a paper filter.

Mixture 2 demonstrated a high dissolving and oxidizing capacity. The recoveries were not significantly lower than those obtained with mixture 1 . Nevertheless, the dissolution reaction was strongly exothermic, and the consistency of the final solution was viscous with consequent difficulty during the filtration phase. Furthermore, it was necessary to use materials resistant to the corrosive action of the acids in use.

Mixture 3 yielded the least satisfactory results in terms of recoveries on CRM. The dissolving and oxidizing capacity was incompleted and the solution generated a lot of foam in the filtration step.

Therefore, all of the samples were digested with mixture 1 because it was the most effective in the mineralization phase and it is the easiest to use in field analysis. The samples treated with $\mathrm{P}_{\mathrm{T}}$ were analysed only with AuNPs-GCE since it shows the best performance using $\mathrm{MW}_{\mathrm{T}}$. In Table 2, it is possible to observe that recoveries were higher than $80 \%$ for all the samples. In particular, very good results were obtained ( $98 \%$ for the SF and $97 \%$ for the TF) with the fresh fish. In fact, the presence of water in the fresh samples facilitates the dissolution of the sample and the extraction of the analyte. This is a very good outcome, since the procedure was developed with the idea of applying it for on-site measurements on fresh fish.

A statistical comparison was made among the results obtained by the different techniques using ANOVA (level of probability $=95 \%$ ). For all the considered samples, $\mathrm{Hg}$ content measured with DMA was not significantly different from those found by ASV using AuNPs-GCE. Instead, using SGE (among the quantifiable samples), the results were significantly different in one case.

The LOQ in the fish-matrix, computed as the minimum amount determined with good trueness (i.e., $\geq 98 \%$ ), was $0.5 \mu \mathrm{g} \mathrm{L}-1$, corresponding to $0.3 \mathrm{mg} \mathrm{kg}^{-1}$ in the fresh sample, in the case of SGE and $0.1 \mu \mathrm{g} \mathrm{L}^{-1}$, corresponding to $0.06 \mathrm{mgkg}^{-1}$ in the fresh sample, in the case of AuNPs-GCE.

Considering that the maximum admissible level of mercury in tuna fish is fixed to $1 \mathrm{mg} \mathrm{kg}^{-1} \mathrm{WF}$ by the Commission Regulation (EU) 420/2011 [42], both voltammetric approaches can be considered suitable to monitor its content in this matrix.

Figure 5 reports the voltammograms referred to the analysis of sample CT2 using SGE voltammogram (a) AuNPs-GCE (b) or AuNPs-GCE coupled to $\mathrm{P}_{\mathrm{T}}$ (c) with the two corresponding standard additions. The reported voltammograms were obtained after the subtraction of the correspondent blank signals. It is possible to observe that higher signals were recorded by AuNPs-GCE 
and then by SGE, even if the concentrations in the voltammetric cell are lower (the sample solutions were diluted with a different ratio in voltammetric cell, namely 1:10 in the case of SGE, and 1:20 in the case of AuNPs-GCE).
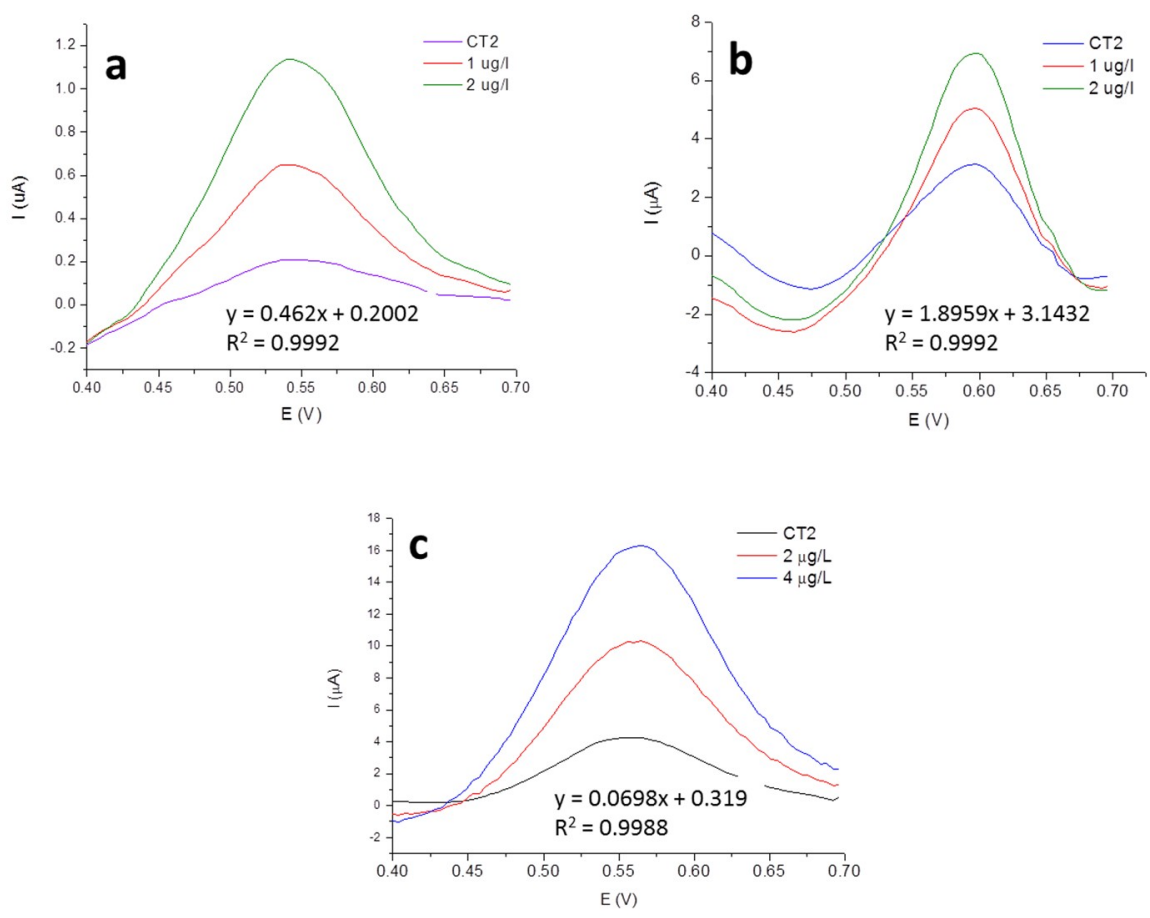

Figure 5. Voltammograms obtained for $\mathrm{Hg}$ quantification in sample CT2 using $\mathrm{MW}_{\mathrm{T}} \mathrm{SGE}$ (a), $\mathrm{MW}_{\mathrm{T}}$-AuNPs-GCE (b) and $\mathrm{P}_{\mathrm{T}}$-AuNPs-GCE (c) with the standard addition method.

For each determination, the corresponding equation of the calibration line and the $\mathrm{R}^{2}$ value are also reported: the latter show the good linearity of the technique.

\subsection{Considerations about the Whole Portable System}

- A concentration as low as $0.5 \mu \mathrm{g} \mathrm{L} \mathrm{L}^{-1}$ in blank solution $\left(0.06 \mathrm{~mol} \mathrm{~L}^{-1} \mathrm{HCl}\right)$ was quantified with three standard additions. The results obtained in the case of the benchtop and the portable instrument were $0.51 \mu \mathrm{g} \mathrm{L}^{-1} \pm 0.02 \mu \mathrm{g} \mathrm{L}^{-1}$ (relative error: 0.03 ; calibration curve: $\mathrm{y}=1.49 \times 10^{-5} \mathrm{x}+7.7 \times$ $10^{-6}, \mathrm{R}^{2}=0.998$ ) and $0.48 \mu \mathrm{g} \mathrm{L}^{-1} \pm 0.03 \mu \mathrm{g} \mathrm{L}^{-1}$ (relative error: 0.05 ; calibration curve: $\mathrm{y}=2.14 \times$ $\left.10^{-5} \mathrm{x}+1.02 \times 10^{-5}, \mathrm{R}^{2}=0.999\right)$, respectively.

- The autonomy of the portable battery guarantees $18 \mathrm{~h}$ of work; recharging the battery at night. Therefore, the possibility of working for the whole next day is guaranteed.

- Comparing the time required for $\mathrm{MW}_{\mathrm{T}}$ with that for $\mathrm{P}_{\mathrm{T}}$, the time determining step is the sample pretreatment, since the duration of the voltammetric analysis is the same. Digestion in a microwave oven requires about two hours for three samples in duplicate; then, the vessel have to be cleaned for the next samples' digestion. Using $\mathrm{P}_{\mathrm{T}}$, the time required for the sample pretreatment was reduced since the samples are treated in disposable Falcon tubes and it is possible to obtain three sample solutions in duplicate per hour.

- AuNPs-GCE shows better analytical performance, and in particular higher sensitivity, than SGE. However, the latter could be the best choice for on-site analysis since AuNP modification requires the use of $\mathrm{N}_{2}$ for the deoxygenation of the Au solution before the deposition and the obtained $\mathrm{Au}$ layer has to be treated with $\mathrm{NaOH}$ for $20 \mathrm{~min}$ and activated. Moreover, SGE can also be used to monitor the $\mathrm{Hg}$ concentration in fish, since the LOQ obtained is lower than the maximum admissible level. 
- Small volumes of reagent could be adopted both for pretreatment and for the analysis step, to reduce the amount of liquid wastes. In particular, it could be very important to reduce the sample solution volume in the voltammetric cell, and consequently the volume of mercury added during the standard additions: spiked sample solutions represent a toxic waste, therefore it is fundamental to collect them and transport them to the laboratory for a proper disposal.

\section{Material and Methods}

\subsection{Apparatus and Reagents}

$\mathrm{M}_{\mathrm{T}}$ of the CRM and the CT samples was carried out by a Milestone MLS-1200 Mega microwave laboratory unit (Milestone, Sorisole, Italy) in tetrafluoromethoxyl bombs.

The benchtop voltammetric analyser was a PGSTAT10 potentiostat (Eco Chemie, Utrecht, the Netherlands) coupled to a 663 VA Metrohm (Herisau, Switzerland) stand. The potentiostat was interfaced to a personal computer; and the software GPES 4.9 (Autolab Software, Metrohm, Herisau, Switzerland) was used to set up the operational conditions and to produce voltammograms.

A small commercial food warmer (Artsana s.p.A. Como, Italy) was used for $\mathrm{P}_{\mathrm{T}}$.

A PalmSens3 portable potentiostat (Thasar s.r.l, Milan, Italy) was also tested to value its applicability for on-site analysis. The potentiostat was connected to a KIA-Topolino magnetic stirrer and interfaced to a laptop computer. The software PSTrace 4.6 (PalmSens BV, Houten The Netherlands) was used to set the process parameters and record the voltammograms.

A portable battery ( $18 \mathrm{~h}$ of autonomy) was used to power the food warmer and the stirrer during the analysis.

A cell with a three-electrode configuration was adopted: a solid gold electrode (SGE) or a AuNPs-GCE prepared from a commercial Metrohm GCE (see Section 3.3) as a WE, a graphite wire as a counter electrode and an $\mathrm{Ag} / \mathrm{AgCl} / \mathrm{KCl}\left(3 \mathrm{~mol} \mathrm{~L}^{-1}\right)$ as a reference electrode.

Morphological characterisation of the electrode surfaces was performed by SEM using a Stereo scan 410 SEM Inspect $F^{\mathrm{TM}}$ with Field Emission Gun (LEICA Microsystems, Wetzlar, Germany).

The surface roughness of the obtained AuNPs-GCE was investigated by AFM using a Danish micro engineering scanning probe microscope (Anton Paar, Graz, Austria), SPM (AFM/Scanning Tunneling Microscope, STM, (Anton Paar, Graz, Austria). This instrument is equipped with a DME Igloo stage with $50 \mu \mathrm{m}$ DS95-50E SPM head for the fluid environment, integrated optical axis on cantilever and total positioning and approach control via a CCD PSU camera (DME 2350, (Anton Paar, Graz, Austria) and a fully digital hold C26 Dualscope/Rasterscope controller (Anton Paar, Graz, Austria).

A Direct Mercury Analyser DMA-80 (FKV Srl, Torre Boldone, BG, Italy) was employed; the measurements were carried out at the Istituto Zooprofilattico Sperimentale del Piemonte, Liguria e Valle d'Aosta (IZSPLV), Torino, Italy. DMA requires regular grade oxygen as a carrier and decomposition gas. The instrument is equipped with a hollow cathode lamp $\left(\lambda_{\mathrm{Hg}}=253.7 \mathrm{~nm}\right)$ and a Si-photodiode sensor (FKV Srl, Torre Boldone, BG, Italy).

A chemometric processing of the experimental results was performed by ANOVA (Addinsoft Inc, Long Island City, NY, USA), with an XLStat 7 software package, used as a Microsoft Excel plug-in (Addinsoft Inc, Long Island City, NY, USA).

Ultrapure water (UPW) supplied by a Milli-Q apparatus (Millipore, Bedford, OH, USA) and analytical grade reagents (Sigma Aldrich, Milan, Italy) were used throughout.

A $1000 \mathrm{mg} \mathrm{L}^{-1}$ standard solution of mercury was prepared from $\mathrm{HgCl}_{2}$ in $0.012 \mathrm{~mol} \mathrm{~L}^{-1} \mathrm{HCl}$ and used to obtain working standards to be added in a voltammetric cell for quantification of the analyte in sample solution.

A $65 \% \mathrm{HNO}_{3} / 30 \% \mathrm{H}_{2} \mathrm{O}_{2}=1: 1$ mixture was used for the digestion of the samples in microwave oven (Milestone, Sorisole, Italy).

For $\mathrm{P}_{\mathrm{T}}$, three different solutions were tested for the extraction of $\mathrm{Hg}$ from the fish matrix, namely, mixture $1: 65 \% \mathrm{HNO}_{3} / 30 \% \mathrm{H}_{2} \mathrm{O}_{2}=1: 1$ (the same as the one adopted for microwave digestion); mixture 
2: $95-97 \% \mathrm{H}_{2} \mathrm{SO}_{4} / 65 \% \mathrm{HNO}_{3} / 70 \% \mathrm{HClO}_{4}=5: 1: 1$ [43]; mixture 3: $65 \% \mathrm{HNO}_{3} / 37 \% \mathrm{HCl} / 30 \% \mathrm{H}_{2} \mathrm{O}_{2}=5: 1: 1$ (suggested by the producer of the microwave oven).

Calibration standards for DMA were prepared using a reference solution of $1000 \mathrm{mg} \mathrm{L}^{-1} \mathrm{Hg}$ preserved in $5 \% \mathrm{HNO}_{3}$. Working standards of 0.1 and $1 \mathrm{mg} \mathrm{L}^{-1}$ were prepared and preserved in $3.7 \%$ $\mathrm{HCl}$ and stored in amber glass vials.

In addition, $100 \mathrm{mg} \mathrm{L}^{-1}$ stock solution of $\mathrm{HAuCl}_{4} \cdot 3 \mathrm{H}_{2} \mathrm{O}$ (Sigma Aldrich, $>99.9 \%$ trace metals basis) in UPW was prepared for the deposition of gold nanoparticles onto the electrode.

\subsection{Samples and Sample Pretreatment}

The CRM Tuna Fish BCR 463, with a concentration of $\mathrm{Hg}=2.85 \mathrm{mg} \mathrm{kg}^{-1} \pm 0.16 \mathrm{mg} \mathrm{kg}^{-1}$, was employed to evaluate the efficiency and the trueness of the measurements carried out by ASV and DMA.

Ten samples of CT were purchased in local supermarkets, coded 1-10 for an univocal identification. Then, each CT was opened and the liquid drained. The samples were firstly grinded in a mortar and then freeze-dried, so as to obtain a powder, which is easier to store.

Two fresh fish slices, respectively of SF and TF, were purchased in local fish markets, and frozen in order to guarantee their maintenance over time.

For analyses by ASV, a pretreatment of the samples was required. Aliquots of $0.5 \mathrm{~g}$ of the CRM and of the freeze-dried samples were transferred into the bombs and digested with a mixture of 3 $\mathrm{mL}$ of $\mathrm{HNO}_{3}$ and $3 \mathrm{~mL}$ of $\mathrm{H}_{2} \mathrm{O}_{2}$. Aliquots of $1 \mathrm{~g}$ were adopted for the fresh samples, due to the high amount of $\mathrm{H}_{2} \mathrm{O}$ present in them (about $60-70 \%$ of the total weight).

For $\mathrm{MW}_{\mathrm{T}}$, the following heating program of the microwave unit was adopted: $250 \mathrm{~W}$ for $1 \mathrm{~min} ; 0$ $\mathrm{W}$ for $1 \mathrm{~min}$; $250 \mathrm{~W}$ for $5 \mathrm{~min}$; $400 \mathrm{~W}$ for $5 \mathrm{~min}$; $650 \mathrm{~W}$ for $5 \mathrm{~min}$; and ventilation for $25 \mathrm{~min}$. The bombs were left to cool to room temperature before opening.

For on-site application, the $\mathrm{P}_{\mathrm{T}}$ was adopted. Aliquots of $0.5 \mathrm{~g}$ of each freeze-dried sample or of $1 \mathrm{~g}$ of fresh samples were transferred into Falcon tubes with the dissolving extraction solution $\left(\mathrm{HNO}_{3} / \mathrm{H}_{2} \mathrm{O}_{2}=1: 1\right)$. The mixture was allowed to react for $10 \mathrm{~min}$ and heated for $20 \mathrm{~min}$ at $60^{\circ} \mathrm{C}$ by immersion in "bain-marie" in a small food warmer suitable to be powered with a simple portable battery (18 $\mathrm{h}$ of autonomy) for use in the field.

In the case of $\mathrm{MW}_{\mathrm{T}}$, sample solutions were filtered through Whatman 5 filters, while, in the case of $\mathrm{P}_{\mathrm{T}}$, sample solutions were filtered through syringe filters to filter the aliquot of sample solution to be transferred directly into the measuring cell. Then, the solutions obtained after each pretreatment procedure were filtered and diluted to $15 \mathrm{~mL}$ with UPW.

In the case of DMA, the analyses were performed directly on the freeze-dried samples, without any pretreatment.

All of the experiments were performed in duplicate and blanks were simultaneously run.

\subsection{Deposition of Gold Nanoparticles onto the Glassy Carbon Electrode}

The GCE surface was polished with $\mathrm{Al}_{2} \mathrm{O}_{3}$ suspension and rinsed with ethanol and water alternatively. The electrode modification with AuNPs was performed keeping the GCE at $-0.8 \mathrm{~V}$ for 6 min in a $100 \mathrm{mg} \mathrm{L}^{-1} \mathrm{HAuCl}_{4} \cdot 3 \mathrm{H}_{2} \mathrm{O}$ solution (corresponding to $50 \mathrm{mg} \mathrm{L}^{-1}$ of $\mathrm{Au}$ ). The nanostructured electrode was maintained in $0.1 \mathrm{M} \mathrm{NaOH}$ until use [20].

Before starting the analyses, ten $\mathrm{CV}$ scans in $0.05 \mathrm{~mol} \mathrm{~L}^{-1} \mathrm{H}_{2} \mathrm{SO}_{4}$ were performed, varying the potential from 0 to 1.6 to $0 \mathrm{~V}$; then, the AuNPs-GCE was activated applying a potential of $0.6 \mathrm{~V}$ for $60 \mathrm{~s}$ while it was stirred in $0.06 \mathrm{~mol} \mathrm{~L}^{-1} \mathrm{HCl}$ solution (see Section 2.1).

The presence of AuNPs onto electrode was confirmed by SEM analyses and by the response of the electrode when subjected to $\mathrm{CV}$, as described in Section 2.1.

An estimation of the roughness of the AuNPs surface was performed by AFM. 


\subsection{Solid Gold Electrode Pretreatment}

At the beginning, the SGE was polished with alumina powder and activated following the same procedure adopted for the AuNPs-GCE. During all the subsequent analyses, hereafter described, the mechanical polishing was no longer performed.

\subsection{SW-ASV Analysis}

Aliquots of the sample solutions obtained by $\mathrm{M}_{\mathrm{T}}$ or $\mathrm{P}_{\mathrm{T}}$ (generally, $2 \mathrm{~mL}$ in the case of SGE, and 1 $\mathrm{mL}$ in the case of AuNPs-GCE), were transferred into the voltammetric cell and diluted to $20 \mathrm{~mL}$ with a $0.06 \mathrm{~mol} \mathrm{~L}^{-1} \mathrm{NaCl}$ solution.

The medium exchange technique was adopted for the ASV analyses. It consists of two steps: (1) during the electrodeposition step, the potential was kept at $0 \mathrm{~V}$ for $120 \mathrm{~s}$; then, the "Hold" function of the potentiostat was set; (2) the sample solution was replaced with a solution of $0.06 \mathrm{molL}^{-1} \mathrm{NaCl}$ and the stripping scan in the range between $0 \mathrm{~V}$ and $0.75 \mathrm{~V}$ was performed. The same instrumental parameters were adopted using both the conventional and the portable potentiostat. The parameter values (frequency $=150 \mathrm{~Hz}$, initial potential $=0 \mathrm{~V}$, final potential $=0.8 \mathrm{~V}$, step potential $=0.004 \mathrm{~V}$, amplitude $=0.03 \mathrm{~V}$, scan rate $=0.6075 \mathrm{~V} / \mathrm{s}$, stirring rate $=2000 \mathrm{rpm}$ ) were optimised by our research group in a previous work [22].

After each measurement, the electrode was kept at $0.80 \mathrm{~V}$ for $30 \mathrm{~s}$ in a mixture of $0.2 \mathrm{~mol} \mathrm{~L}^{-1}$ $\mathrm{HClO}_{4} / 3 \mathrm{mmol} \mathrm{L}{ }^{-1} \mathrm{NaCl} / 1 \mathrm{mmol} \mathrm{L}{ }^{-1} \mathrm{NaEDTA}$, in order to remove residues of mercury from its surface (Metrohm, Application Bulletin No 96/4e).

The standard addition method was adopted for the evaluation of the concentration of mercury in all investigated samples. Well defined peaks were obtained by subtracting the blank signal from the sample solution signal.

\subsection{DMA Analysis}

DMA was used to determine the concentration of total mercury, as reported in the U.S. EPA Method 7473 (EPA, Method 7473, 2007). Calibration graphs of 0-20 ng and 20-500 ng of mercury were created by injecting increasing volumes of 0.1 and $1 \mathrm{mg} \mathrm{L}^{-1}$ mercury standard solutions, respectively, into quartz sample boats.

DMA performs thermal decomposition, catalytic reduction, amalgamation, desorption and atomic absorption spectroscopy to treat and analyse solid or liquid samples for mercury. The process takes about $5 \mathrm{~min}$. The analyses were carried out using the following parameters: drying time/temperature: $90 \mathrm{~s}$ at $200{ }^{\circ} \mathrm{C}$; decomposition ramp: $120 \mathrm{~s}$ at $750{ }^{\circ} \mathrm{C}$; decomposition hold: $90 \mathrm{~s}$ at $750{ }^{\circ} \mathrm{C}$; catalyst temperature: $600{ }^{\circ} \mathrm{C}$; purge time: $60 \mathrm{~s} ; 12 \mathrm{~s}$ at $900^{\circ} \mathrm{C}$; recording time: $60 \mathrm{~s}$; oxygen flow: $120 \mathrm{~mL} / \mathrm{min}$. Aliquots of each sample (about $0.1 \mathrm{~g}$ ) were transferred into the sample boats and directly analysed without any pretreatment.

\section{Conclusions}

Even if the ASV analysis in the field is possible thanks to the availability of the modern portable potentiostat, the pretreatment step with microwave oven does not permit the on-site extraction of the analyte. A simple treatment with a mixture 1:1 of $\mathrm{HNO}_{3}: \mathrm{H}_{2} \mathrm{O}_{2}$ using a commercial food warmer permits quantitatively extracting $\mathrm{Hg}$ from the sample and is compatible with field operation. The results obtained with the on-site procedure developed in this work are consistent with those obtained with the conventional microwave digestion coupled to a benchtop voltammetric analyser and with DMA.

The suitability of ASV both with solid and nanostructured gold electrodes for the determination of mercury in fish was demonstrated. In the case of in-cell $\mathrm{Hg}$ concentrations higher than $0.7 \mu \mathrm{g} \mathrm{L}{ }^{-1}$, both electrodes provide very accurate determinations, while only the AuNPs-GCE permits quantifying lower concentrations, thanks to the higher surface area of the gold nanoparticles. In particular, this proposed electrode shows high sensitivity, good selectivity, long-term stability and great repeatability. Mercury 
detection at the AuNPs-GCE showed an LOQ in fish-matrix of $0.1 \mu \mathrm{g} \mathrm{L}-1$ (Hg cell concentration), corresponding to $0.06 \mathrm{mg} \mathrm{kg}^{-1}$ wet fish. The simplicity of the procedure requested for the electrode modification and the good correlation between the results obtained by DMA and ASV with AuNPs-GCE confirm that the latter can be considered an effective and an inexpensive alternative to other more common techniques for the determination of mercury in fish. Moreover, the SGE can also be used to monitor $\mathrm{Hg}$ concentration in fish, since the maximum admissible level of this element is higher than the LOQ value.

The proposed procedure is simple, fast and inexpensive; it can be used also by unqualified personnel. It can be applied for fast screening tests, allowing for the increase of controls on fish batches, with a view to reducing the risks to the health of consumers. The next steps will be to reduce the volume of the reagents both for the pretreatment and for the analysis step in order to reduce the liquid wastes requiring disposal.

Author Contributions: Conceptualization, O.A.; Methodology, A.G. and R.T.; Validation, M.C.A., and F.D.; Formal Analysis, A.R.R. and S.S.; Investigation, A.R.R. and A.G.; Data Curation, M.M.; Writing-Original Draft Preparation, A.R.R., A.G., O.A., R.T. and S.B.; Writing—Review and Editing, A.G.; O.A. and F.D.; Supervision, Agnese Giacomino.; Project Administration, A.G.; Funding Acquisition, A.G. and F.D.

Funding: This study was funded by the Cassa di Risparmio di Torino (CRT) Foundation within the framework of the "Richieste Ordinarie 2016" projects.

Acknowledgments: The authors are grateful to Thasar s.r.1 (Milan, Italy) for their technical support with Palmsens 3. The authors are grateful to Linda Pastero, Department of Earth Sciences for AFM analysis.

Conflicts of Interest: The authors declare no conflict of interest

\section{References}

1. Horowitz, H.M.; Jacob, D.J.; Amos, H.M.; Streets, D.G.; Sunderland, E.M. Historical mercury releases from commercial products: Global environmental implications. Environ. Sci. Technol. 2014, 48, 10242-10250. [CrossRef]

2. Johansson, K.; Bergbäck, B.; Tyler, G. Impact of atmospheric long-range transport of lead, mercury and cadmium on the Swedish Forest Environment. Water Air Soil Pollut. Focus 2001, 1, 279-297. [CrossRef]

3. Morel, F.M.M.; Kraepiel, A.M.L.; Amyot, M. The chemical cycle and bioaccumulation of mercury. An. Rev. Ecol. System. 1998, 29, 543-566. [CrossRef]

4. Valdersnes, S.; Fecher, P.; Maage, A.; Julshamn, K. Collaborative study on determination of mono methylmercury in seafood. Food Chem. 2016, 194, 424-431. [CrossRef] [PubMed]

5. Gosnell, K.J.; Mason, R.P. Mercury and methylmercury incidence and bioaccumulation in plankton from the central Pacific Ocean. Marine Chem. 2015, 177, 772-780. [CrossRef]

6. Falandysz, J.; Chwir, A.; Wyrzykowska, B. Total mercury contamination of some fish species in the firth of vistula and the lower Vistula river, Poland. Polish J. Environ. Studies 2000, 9, 335-339.

7. Baker, R.F.; Blanchfield, P.J.; Paterson, M.J.; Flett, R.J.; Wesson, L. Evaluation of nonlethal methods for the analysis of mercury in fish tissue. Trans. Amer. Fisheries Soc. 2004, 133, 568-576. [CrossRef]

8. Jun Shao, L.J.; Gan, W.E.; Su, Q.D. Determination of total and inorganic mercury in fish samples with on-line oxidation coupled to atomic fluorescence spectrometry. Analy. Chim. Acta 2006, 562, 128-133. [CrossRef]

9. Squadrone, S.; Benedetto, A.; Brizio, P.; Prearo, M.; Abete, M.C. Mercury and selenium in European catfish (Silurus glanis) from Northern Italian Rivers: Can molar ratio be a predictive factor for mercury toxicity in a top predator? Chemosphere 2015, 119, 24-30. [PubMed]

10. Martín-Yerga, D.; González-García, M.B.; Costa-García, A. Electrochemical determination of mercury: A review. Talanta 2013, 116, 1091-1095. [CrossRef]

11. EPA Method 7472. Available online: https://www.epa.gov/sites/production/files/2015-12/documents/7472.pdf (accessed on 17 May 2019).

12. Radulescu, M.C.; Danet, A.F. Mercury determination in fish samples by chronopotentiometric stripping analysis using gold electrodes prepared from recordable CDs. Sensors 2008, 8, 7157-7171. [CrossRef] [PubMed] 
13. Meucci, V.; Laschi, S.; Minunni, M.; Pretti, C.; Intorre, L.; Soldani, G.; Mascini, M. An optimized digestion method coupled to electrochemical sensor for the determination of $\mathrm{Cd}, \mathrm{Cu}, \mathrm{Pb}$ and $\mathrm{Hg}$ in fish by square wave anodic stripping voltammetry. Talanta 2009, 77, 1143-1148. [CrossRef]

14. Tamer, U.; Oymak, T.; Ertas, N. Voltammetric determination of mercury(II) at poly(3-hexylthiophene) film electrode. Effect of halide ions. Electroanalysis 2007, 19, 2565-2570. [CrossRef]

15. Afkhami, A.; Madrakian, T.; Sabounchei, S.J.; Rezaei, M.; Samiee, S.; Pourshahbaz, M. Construction of a modified carbon paste electrode for the highly selective simultaneous electrochemical determination of trace amounts of mercury (II) and cadmium (II). Sensors Actuators B 2012, 161, 542-548. [CrossRef]

16. Afkhami, A.; Madrakian, T.; Ghaedi, H.; Rezaeivala, M. Fabrication and application of a new modified electrochemical sensor using nano-silica and a newly synthesized Schiff base for simultaneous determination of $\mathrm{Cd}^{2+}, \mathrm{Cu}^{2+}$ and $\mathrm{Hg}^{2+}$ ions in water and some foodstuff samples. Analy. Chim. Acta 2013, 771, 21-30. [CrossRef]

17. Bagheri, H.; Afkhami, A.; Khoshsafar, H.; Rezaei, M.; Shirzadmehr, A. Simultaneous electrochemical determination of heavy metals using a triphenylphosphine/MWCNTs composite carbon ionic liquid electrode. Sensors Actuators B 2013, 186, 451-460. [CrossRef]

18. Azadmehr, F.; Zarei, K. Ultrasensitive determination of ceftizoxime using pencil graphite electrode modified by hollow gold nanoparticles/reduced graphene oxide. Arabian J. Chem. 2018. [CrossRef]

19. Bernalte, E.; Sánchez, C.M.; Gil, E.P. Determination of Mercury in indoor dust samples by ultrasonic probe microextraction and stripping voltammetry on gold nanoparticles-modified screen-printed electrodes. Talanta 2012, 97, 187-192. [CrossRef]

20. Wang, N.; Lin, M.; Dai, H.; Ma, H. Functionalized goldnanoparticles/reducedgrapheneoxide nanocomposites for ultrasensitive electrochemical sensing of mercury ions based on thymine-mercury-thymine structure. Biosens. Bioelectron. 2016, 79, 320-326. [CrossRef] [PubMed]

21. Ojani, R.; Maleki, J.-B.R.; Asghar, A.; Saeid, S. Simultaneous and sensitive detection of dopamine and uric acid using a poly(L-methionine)/gold nanoparticle-modified glassy carbon electrode. Chin. J. Catal. 2014, 35, 423-429. [CrossRef]

22. Liu, Z.; Puumala, E.; Chen, A. Sensitive electrochemical detection of $\mathrm{Hg}$ (II) via a FeOOH modified nanoporous gold microelectrode. Sensors Actuators B Chem. 2019, 287, 517-525. [CrossRef]

23. Roditi, E.; Tsetsoni, M.; Kokkinos, C.; Economou, A. Integrated on-chip sensor with sputtered Ag-Au-Au electrodes for the voltammetric determination of trace $\mathrm{Hg}(\mathrm{II})$. Sensors Actuators B Chem. 2019, 286, 125-130. [CrossRef]

24. Jin, H.; Zhang, M.; Wei, M.; Cheng, J.H. A voltammetric biosensor for mercury(II) using reduced graphene oxide@gold nanorods and thymine-Hg(II)-thymine interaction. Microchim. Acta 2019, 186, $264-272$. [CrossRef]

25. Wu, Z.; Cui, T. Shrink-Induced Microelectrode Arrays for Trace Mercury Ions Detection. Iee Sensors J. 2019, 19, 2435-2441. [CrossRef]

26. Ponram, M.; Balijapalli, U.; Sambath, B.; Kulathu Iyer, S.; Kakaraparthi, H.; Thota, G.; Bakthavachalam, V.R.; Cingaram, R.; Sung-Ho, J.; Sundaramurthy, K.N. Inkjet-printed phosphorescent Iridium(III) complex based paper sensor for highly selective detection of $\mathrm{Hg}^{2+}$. Dyes Pigments 2019, 163, 176-182. [CrossRef]

27. Manikandan, R.; Deepa, P.N.; Narayanan, S.S. Anodic stripping voltammetric determination of $\mathrm{Hg}$ (II) using poly xylenol orange film modified electrode. Ionics 2019, 25, 1387-1394. [CrossRef]

28. Hasanjani, A.R.H.; Zarei, K. An electrochemical sensor for attomolar determination of mercury(II) using DNA/poly-L-methionine-gold nanoparticles/pencil graphite electrode. Biosensors Bioelectr. 2019, 128, 1-8. [CrossRef]

29. Teodoro, K.B.R.; Migliorini, F.L.; Facure, M.H.M.; Correa, D.S. Conductive electrospun nanofibers containing cellulose nanowhiskers and reduced graphene oxide for the electrochemical detection of mercury(II). Carbohydrate Poly. 2019, 207, 747-754. [CrossRef]

30. Pramanik, K.; Sarkar, P.; Bhattacharyay, D. Semi-quantitative colorimetric and supersensitive electrochemical sensors for mercury using rhodamine b hydrazide thio derivative. J. Mol. Liquids 2019, 276, 141-152. [CrossRef]

31. Jeromiyas, N.; Elaiyappillai, E.; Kumar, A.S.; Huang, S.T.; Mani, V. Bismuth nanoparticles decorated graphenated carbon nanotubes modifie d screen-printe d electrode for mercury detection. J. Taiwan Instit. Chem. Eng. 2019, 95, 466-474. [CrossRef] 
32. Ramalingam, M.; Ponnusamy, V.K.; Sangilimuthu, S.N. A nanocomposite consisting of porous graphitic carbon nitride nanosheets and oxidized multiwalled carbon nanotubes for simultaneous stripping voltammetric determination of cadmium(II), mercury(II), lead(II) and zinc(II). Microchim. Acta 2019, 186, 69. [CrossRef]

33. Wu, W.; Jia, M.; Wang, Z.; Zhang, W.; Zhang, Q.; Liu, G.; Zhang, Z.; Li, P. Simultaneous voltammetric determination of cadmium(II), lead(II), mercury(II), zinc(II), and copper(II) using a glassy carbon electrode modified with magnetite $\left(\mathrm{Fe}_{3} \mathrm{O}_{4}\right)$ nanoparticles and fluorinated multiwalled carbon nanotubes. Microchim. Acta 2019, 186, 97. [CrossRef]

34. Abollino, O.; Giacomino, A.; Ginepro, M.; Malandrino, M.; Zelano, I. Determination of mercury by anodic stripping voltammetry with a gold nanoparticle-modified glassy carbon electrode. Electroanalysis 2012, 24, 727-734. [CrossRef]

35. Abollino, O.; Giacomino, A.; Malandrino, M.; Piscionieri, G.; Mentasti, E.; Mentasti, E. Determizione del mercurio mediante voltammetria di stripping anodico con elettrodo solido d'oro. Electroanalysis 2008, 20, 75-83. [CrossRef]

36. Giacomino, A.; Abollino, O.; Malandrino, M.; Mentasti, E. Parameters affecting the determination of mercury by anodic stripping voltammetry using a gold electrode. Talanta 2008, 85, 266-273. [CrossRef]

37. Salaun, P.; Planer-Friedrich, B.; Van den Berg, C.M.G. Inorganic arsenic speciation in water and seawater by anodic stripping voltammetry with a gold microelectrode. Analy. Chim. Acta 2007, 585, 312-322. [CrossRef]

38. Priano, G.; González, G.; Günther, M.; Battaglini, F. Disposable Gold Electrode Array for Simultaneous Electrochemical Studies. Electroanalysis 2008, 20, 91-97. [CrossRef]

39. Dai, X.; Nekrassova, O.; Hyde, M.E.; Compton, R.G. Anodic stripping voltammetry of arsenic (III) using gold nanoparticle-modified electrodes. Analy. Chem. 2004, 76, 5924-5929. [CrossRef]

40. Shu, H.; Chang, G.; Wang, Z.; Li, P.; Zhang, Y.; He, Y. Pulse laser deposition fabricating gold nanoclasters on a glassy carbon surface for nonenzymatic glucose sensing. Analy. Sci. 2015, 31, 609-613. [CrossRef]

41. Detcheva, A.; Grobecker, K.H. Analytical Note Determination of $\mathrm{Hg}$, Cd, Mn, Pb and Sn in seafood by solid sampling Zeeman atomic absorption spectrometry. Spectrochimica Acta Part B 2006, 61, 454-459. [CrossRef]

42. Regulation (EU) No 420/2011 of the European Parliament and of the Council of April 29th 2011. European: Amending Regulation (EC) No 1881/2006 of the European Parliament. Available online: https:/eur-lex.europa.eu/LexUriServ/ LexUriServ.do?uri=CONSLEG:2006R1881:20120901:EN:PDF (accessed on 17 May 2019).

43. Voegborlo, R.B.; Adimado, A.A. A simple classical wet digestion technique for the determination of total mercury in fish tissue by cold vapour atomic absorption spectrometry in a low technology environment. Food Chem. 2010, 123, 936-940. [CrossRef]

Sample Availability: Sample Availability: Not available.

(C) 2019 by the authors. Licensee MDPI, Basel, Switzerland. This article is an open access article distributed under the terms and conditions of the Creative Commons Attribution (CC BY) license (http://creativecommons.org/licenses/by/4.0/). 